\title{
STATISTICAL DYNAMICS
}

A Stochastic Approach to Nonequilibrium Thermodynamics 
This page is intentionally left blank 


\title{
STATISTICAL

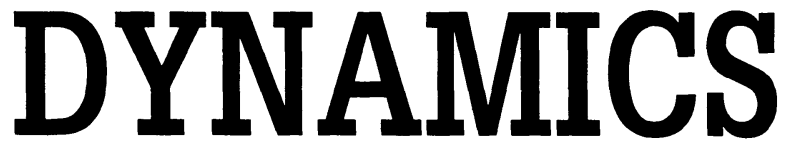

A Stochastic Approach to

Nonequilibrium Thermodynamics

\author{
R. F. Streater \\ Department of Mathematics \\ King's College \\ London
}




\section{Distributed by}

World Scientific Publishing Co Pte Ltd

P O Box 128, Farrer Road, Singapore 9128

USA office: Suite 1B, 1060 Main Street, River Edge, NJ 07661

UK office: 57 Shelton Street, Covent Garden, London WC2H 9HE

\section{British Library Cataloguing-in-Publication Data \\ A catalogue record for this book is available from the British Library.}

\section{Library of Congress Cataloging-in-Publication Data}

Streater, R. F.

Statistical dynamics : a stochastic approach to nonequilibrium thermodynamics / R. F. Streater.

p. $\quad \mathrm{cm}$.

ISBN 1-86094-002-1 ISBN 1-86094-004-8 (pbk)

1. Nonequilibrium thermodynamics -- Statistical methods.

2. Stochastic processes. I. Title.

QC318.I7S768 1995

530.1'3--dc20

\section{Copyright $\odot 1995$ by Imperial College Press}

All rights reserved. This book, or parts thereof, may not be reproduced in any form or by any means, electronic or mechanical, including photocopying, recording or any information storage and retrieval system now known or to be invented, without written permission from the Publisher.

For photocopying of material in this volume, please pay a copying fee through the Copyright Clearance Center, Inc., 222 Rosewood Drive, Danvers, Massachusetts 01923, USA.

This book is printed on acid-free paper.

Printed in Singapore by Uto-Print 


\section{Preface}

This book grew out of lectures given at Virginia Tech. in 1989-1991, and continued at King's College, London. The first half is suitable as a text for a course of one semester, being part of a programme for students of mathematics or physics pursuing a degree at the level of the M. Sc., M. Sci., M. Phys. or M. Math. The second half, which is undoubtedly harder, might be used as a course-book for a more challenging course or as a source for project work at the M. Sc. level, or as a guide to research work leading to the M. Phil.

The author is indebted to many students and friends for help: E. B. Davies, A. Uhlmann, B. Crell, B. Luffman, L. Rondoni, S. Koseki, F. Behmardi and C. Connaughton have been particularly generous. He owes the idea of (12.3) to V. Jaksic. The author was introduced to cotransport by Professor R. J. Naftalin, of the Department of Physiology, King's College, who also kindly drew the pictures using the Stella II 2.2.1 programme for differential equations, produced by High Performance Systems.

R. F. S. May 1995. 
This page is intentionally left blank 


\section{Contents}

Preface v v

I Classical Statistical Dynamics $\quad 1$

1 Introduction 3

2 Probability Theory 11

2.1 Sample Spaces and States . . . . . . . . . . . . . . . . 11

2.2 Random Variables, Algebras . . . . . . . . . . . . . . . 21

2.3 Entropy ........................... 30

2.4 Exercises . . . . . . . . . . . . . . . 33

3 Linear Dynamics $\quad 37$

3.1 Reversible Dynamics . . . . . . . . . . . . . . . . 37

3.2 Random Dynamics . . . . . . . . . . . . . . . . . . 41

3.3 Convergence to Equilibrium . . . . . . . . . . . 50

3.4 Markov Chains . . . . . . . . . . . . . . . 55

3.5 Exercises . . . . . . . . . . . . . . . 57

4 Isolated Dynamics $\quad 61$

4.1 The Boltzmann Map . . . . . . . . . . . . . . . . . 61

4.2 The Heat-Particle . . . . . . . . . . . . . . . . . . 74

4.3 Activity-led Reactions . . . . . . . . . . . . . . 80

4.4 Exercises . . . . . . . . . . . . . . . . . . 88

5 Isothermal Dynamics $\quad 91$

5.1 Legendre Transforms . . . . . . . . . . . . . . . . . . . 92

5.2 The Free-energy Theorem . . . . . . . . . . . . . . . . . 94

5.3 Chemical Kinetics . . . . . . . . . . . . . . . . . . . . . . . 98

5.4 Convergence in Norm . . . . . . . . . . . . . . . . 104

5.5 Dilation of Markov Chains . . . . . . . . . . . . . . 113 
5.6 Exercises . . . . . . . . . . . . . . . . 116

6 Driven Systems 117

6.1 Sources and Sinks . . . . . . . . . . . . . . . 117

6.2 A Poor Conductor . . . . . . . . . . . . . . . 118

6.3 A Driven Chemical System . . . . . . . . . . . . . . . . 121

6.4 How to Add Noise . . . . . . . . . . . . . . . 127

6.5 Exercises . . . . . . . . . . . . . . . . . . . 129

\section{Quantum Statistical Dynamics 131}

$\begin{array}{lll}7 & \text { Introduction } & 133\end{array}$

8 Quantum Probability 139

8.1 Algebras of Observables . . . . . . . . . . . . . 139

8.2 States . . . . . . . . . . . . . . 146

8.3 Quantum Entropy . . . . . . . . . . . . . . . . . 152

8.4 Exercises . . . . . . . . . . . . . . . . 156

9 Linear Quantum Dynamics 159

9.1 Reversible Dynamics . . . . . . . . . . . . . . . . . . . 159

9.2 Random Quantum Dynamics . . . . . . . . . . . . . . 162

9.3 Quantum Dynamical Maps . . . . . . . . . . . . . . . 165

9.4 Exercises . . . . . . . . . . . . . . . . . . . . 171

10 Isolated Quantum Dynamics 173

10.1 The Quantum Boltzmann Map . . . . . . . . . . . . 173

10.2 The Quantum Heat-Particle . . . . . . . . . . . . . . 176

10.3 Fermions and Hard-core Ions . . . . . . . . . . . . . . . 190

10.4 The Quantum Boltzmann Equation . . . . . . . . . . . . . 204

10.5 Exercises . . . . . . . . . . . . . . . . . . 212

11 Isothermal and Driven Systems 215

11.1 Isothermal Quantum Dynamics . . . . . . . . . . . . . 215

11.2 Convergence to Equilibrium . . . . . . . . . . . . . 221

11.3 Driven Quantum Systems . . . . . . . . . . . . . . . 223

11.4 Exercises . . . . . . . . . . . . . . . . . . 227

12 Infinite Systems $\quad 229$

12.1 The Algebra of an Infinite System . . . . . . . . . . . . . 230

12.2 The Reversible Dynamics . . . . . . . . . . . . . . . . . . 231

12.3 Return to Equilibrium . . . . . . . . . . . . . . . 234 
12.4 Irreversible Linear Dynamics . . . . . . . . . . . . . . 237

12.5 A Model in Infinite Volume . . . . . . . . . . . . . 240

12.6 Exercises . . . . . . . . . . . . . . . . . . . . 242

13 Generalised Temperatures $\quad 243$

13.1 The Jaynes-Ingarden Theory . . . . . . . . . . . . . . . . . . 243

13.2 Non-linear Ising Dynamics . . . . . . . . . . . . . . . 246

13.3 Ising Model Close to Equilibrium . . . . . . . . . . . . . . 250

13.4 Non-linear Heisenberg Model . . . . . . . . . . . . . . . 252

13.5 Exercises . . . . . . . . . . . . . . . . . 258

$\begin{array}{ll}\text { Bibliography } & 259\end{array}$

$\begin{array}{ll}\text { Index } & 269\end{array}$ 